\title{
Research and Development Expenditures and Economic Growth in the EU: A Panel Data Analysis
}

\author{
Rita Freimane ${ }^{1}$, Signe Bāliņa ${ }^{2}$ \\ ${ }^{1,2}$ University of Latvia
}

\begin{abstract}
The main aim of the paper is to investigate the empirical relationship between research and development (R\&D) expenditures and economic growth in the European Union member states in the period of 2000-2013. The empirical analysis is based on panel data regressions. The estimated model is the production function type standard growth model extended with R\&D stock variable. The results show a statistically significant impact of R\&D expenditures on the economic growth in the EU countries. The significance for $R \& D$ coefficient remains robust to different sub-periods, but the level of significance decreases as a sub-sample of new EU countries was considered.
\end{abstract}

Keywords - Economic growth, panel data analysis, research and development expenditures.

\section{INTRODUCTION}

For achieving a long-term economic growth, the amount of investments in research and development (R\&D) is highly important. R\&D plays a major role in innovation, raising productivity and increasing economic growth (Romer, 1994). Therefore, theoretically R\&D expenditures have a positive and persistent effect on growth. However, empirically there are problems in effect measuring due to direct and indirect effects of different types of $R \& D$. That is the reason for numerous empirical studies, which differ greatly in terms of aggregated level (companies, industries or countries), sources of data (time periods, countries) and measurements of key variables (stocks, flows or differences). Therefore, the results of these studies are not directly comparable; however, in general, the empirical results confirm theoretical assumptions.

The aim of the present paper is to investigate the role of research and development expenditures for the economic growth of all EU countries and compare the findings in two subgroups: old and new member states with the application of panel data econometric modelling.

Numerous studies also deal with the panel data analysis in R\&D and growth relationship evaluation. Results vary for different panels, time periods, variables and econometric methods. Useful literature review about the aggregate level effects of R\&D was performed by Svensson (2008). He compared results of developed and developing countries. The main finding was that there was no link between $R \& D$ and growth in poor countries, but a significant positive effect was observed in the developed countries.

Silaghi et al. (2014) analysed business and private R\&D expenditures in Central and Eastern European Countries (CEECs). Their conclusions were: "A dynamic panel estimation results showed a statistically significant impact of business R\&D on economic growth in new EU member states.
Public R\&D was found to be with neutral effect: did not stimulate growth, but also did not crowd out private R\&D." They also reported that total R\&D in CEECs did not appear to be statistically significant in any specification (the period was between 1998 and 2008).

Huňady and Orviska (2014) based their research on panel data regression for 26 selected EU countries in the period of 1999-2011. Results of their research suggested a positive impact of $R \& D$ expenditures on the economic growth when considering a two-year lag, at the same time the effect was negative for the current year.

Gumus and Celikay (2015) analysed R\&D expenditure contribution to the economic growth, comparing developed and developing countries. They found: "R\&D expenditure has a positive and significant effect on economic growth for all countries in the long run, but for developing countries the effect is weak in the short run but strong in the long run." They considered all EU countries to be developed.

As the literature review shows, there is still an open question about total R\&D expenditure effect on economic growth in the EU countries. From previous studies we expect that statistically significant and positive impact is at least in the group of old EU member states. However, with respect to convergence speed of new EU countries, R\&D expenditure could have a more significant effect at least in recent years. To our knowledge, there are not panel data studies for all EU countries where dynamic panel results (short-run and long-run effect estimates) are obtained.

The remainder of the paper is as follows: Section II describes methodology and data, Section III presents empirical results, and section IV summarises conclusions.

\section{METHODOLOGY AND DATA}

The model was built like a standard growth equation model corresponding to the production function that adds R\&D among other types of the capital, like in (1):

$$
\begin{aligned}
& \ln Y_{i, t}=\beta_{0} \ln Y_{i, t-1}+\beta_{1} \ln K_{i, t}+\beta_{2} \ln R D s_{i, t}+ \\
& +\beta_{3} \ln H C_{i, t}+\beta_{4} \ln F D I_{i, t}+\beta_{5} X_{i, t}+\eta_{i}+\varepsilon_{i, t}
\end{aligned}
$$

where $Y$ is real GDP per person employed, $K$ is domestic investment, $R D s$ is the research and development stocks calculated as the share of R\&D expenditure stocks on GDP. HC is labour force with tertiary education as percentage of total labour force and it is used as a proxy for human capital (detailed description of the variables and data sources are presented in 
Table I). FDI is foreign direct investment stock as percentage of GDP, and $X$ represents a set of control variables: such as openness and government balance. $\eta_{i}$ represents the individual fixed effects specific to each country, and $\varepsilon_{i, t}$ is an error term assumed to be homoscedastic and with no serial correlation. Like in Silaghi et al. (2014), the impact of labour force on the dependent variable is captured by the way how it is defined. Silaghi et al. (2014) calculated GDP per working age population, but we decided that GDP per person employed could be a more precise measurement for our purpose.

Usually estimations of a production function (like in (1)) are related to a choice between two frameworks: standard neoclassical and endogenous growth. Like in the studies by Goel and Ram (1994) and Sigahi et al. (2014), we did not test these two frameworks and did not consider explicitly restrictions that were to be imposed on the production function.

Estimation of panel data models is quite complicated. In the context of panel data, we must deal with unobserved heterogeneity, autocorrelation in the residuals, as well as with the possibility of endogeneity problems. For example, FDI and R\&D stocks could be dependent on economic growth. To solve these problems, we chose to obtain dynamic panel data estimators using the differenced Generalized Method of Moments (GMM) with Arellano-Bond type instruments (see Arellano, Bond, 1991):

$$
\begin{aligned}
& \Delta \ln Y_{i, t}=\beta_{0} \Delta \ln Y_{i, t-1}+\beta_{1} \Delta \ln K_{i, t}+\beta_{2} \Delta \ln R D s_{i, t} \\
& +\beta_{3} \Delta \ln H C_{i, t}+\beta_{4} \Delta \ln F D I_{i, t}+\beta_{5} \Delta X_{i, t}+\Delta \varepsilon_{i, t}
\end{aligned}
$$

where $\Delta$ denotes first difference of a variable.

Correlation of the residuals and endogeneity problem is corrected by instrumenting $\Delta \ln Y_{i, t-1}$ with various dependent variable lags ( 2 or 3 years), and FDI and RDs were instrumented with their values that lagged more than 1 period behind. Different lag combinations were used to test robustness of results, and outcomes were mainly quite similar (tables of results are available upon request). Estimated coefficients of (2) are short-term estimates that can be interpreted as an immediate percentage change in the dependent variable when a factor value temporarily increases by $1 \%$, but all other factors do not change. The long-term coefficients can be calculated from the error correction form (see Silaghi et al., 2014) by the following formulas:

$$
\begin{gathered}
\phi=\beta_{0}-1 \\
\theta_{i}=\frac{\beta_{i}}{1-\beta_{0}}, i=1, \ldots, 5
\end{gathered}
$$

where $\phi$ is an error correction coefficient, and $\theta_{i}$ are respective long-run coefficients. Coefficients $\theta_{i}$ (4) reflect the long-run change in the dependent variable due to a permanent increase in the factor, with assumption that all other factors do not change. An error correction term $\phi$ (3) reflects convergence towards the steady state, from which we expect it to be negative and less than unity by an absolute value.

The data for modelling were mainly taken from the Eurostat database, but additionally we used the Unctad and World Bank databases. Growth was measured as GDP constant prices of year 2000 (detailed description is provided in Table I). To capture the impact of labour on the dependent variable, we chose to use GDP per person employed. Data about labour force were also retrieved from Eurostat. FDI stock series were taken from the Unctadstat database. As R\&D variable is available only in flows, the stocks were calculated by the perpetual inventory method that was used throughout the related literature and also applied to the present research. Like in the studies by Parham (2007) and Krammer (2010), we tried different depreciation rates, but for the presented results we used a depreciation rate of $15 \%$. Sensibility analysis shows that results of regression do not change significantly with the chosen depreciation rate. PIM method in equation form (4):

$$
K_{R, t+1}=(1-\delta) K_{t}+R_{t}
$$

where $K_{R, t+1}$ is the R\&D stock in the year $(t+1), \delta$ is a constant rate of depreciation, $K_{t}$ is the $\mathrm{R} \& \mathrm{D}$ stock in the year $t$, and $R_{t}$ is the R\&D expenditure in the year $t$.

TABLE I

DESCRIPTION OF VARIABLES

\begin{tabular}{|l|l|l|}
\hline \multicolumn{1}{|c|}{ Variable } & \multicolumn{1}{|c|}{ Description } & \multicolumn{1}{c|}{ Source } \\
\hline $\ln Y_{i, t}$ & $\begin{array}{l}\text { Natural logarithm of GDP per person employed, million euro, chain-linked volumes, the reference } \\
\text { year 2000 }\end{array}$ & Eurostat \\
\hline $\ln K_{i, t}$ & $\begin{array}{l}\text { Natural logarithm of domestic physical capital stock. Computed as a difference in physical stock and } \\
\text { FDI inflows, percentage of GDP }\end{array}$ & $\begin{array}{l}\text { Authors' calculation, based on } \\
\text { Eurostat and Unctad data }\end{array}$ \\
\hline $\ln F D I_{i, t}$ & Natural logarithm of Foreign Direct Investments, stocks, percentage of GDP & Unctad, Eurostat \\
\hline $\ln R D s_{i, t}$ & Natural logarithm of R\&D expenditures (stocks) as a percentage of GDP & $\begin{array}{l}\text { Authors' calculation, based on } \\
\text { Eurostat }\end{array}$ \\
\hline $\ln H C_{i, t}$ & Natural logarithm of labour force with tertiary education (\% of total labour force) & World Bank \\
\hline$G_{-}$balance $_{i, t}$ & Net surplus(+)/net deficit (-) of general government as percentage of GDP & Eurostat \\
\hline
\end{tabular}


The same method was used for derivation of domestic physical capital stock, and depreciation rate was chosen to be $5 \%$.

There are findings in the literature that in the absence of human capital as a factor in the model, R\&D coefficients usually are overestimated (Caselli et al., 1996; Sequeira, 2008). There are different variants of substitutes for human capital in the literature: enrolment data, attainment and average years of education etc. Due to data availability for all EU countries in the specified time period, we decided to use labour force with tertiary education ( $\%$ of total labour force) as a proxy for human capital.

There is a great dispersion in R\&D activity and growth across the EU member states. Table II presents average R\&D expenditures as a percentage of GDP during the periods of 2000-2007, 2008-2009, 2010-2013, and averages for all periods of 2000-2013 and 2013. Additionally, the last column shows national targets under the EU's growth strategy "Europe 2020". Countries in Table II were sorted from the largest to the smallest R\&D with respect to 2000-2013 averages.

TABLE II

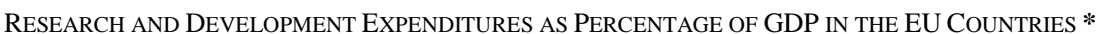

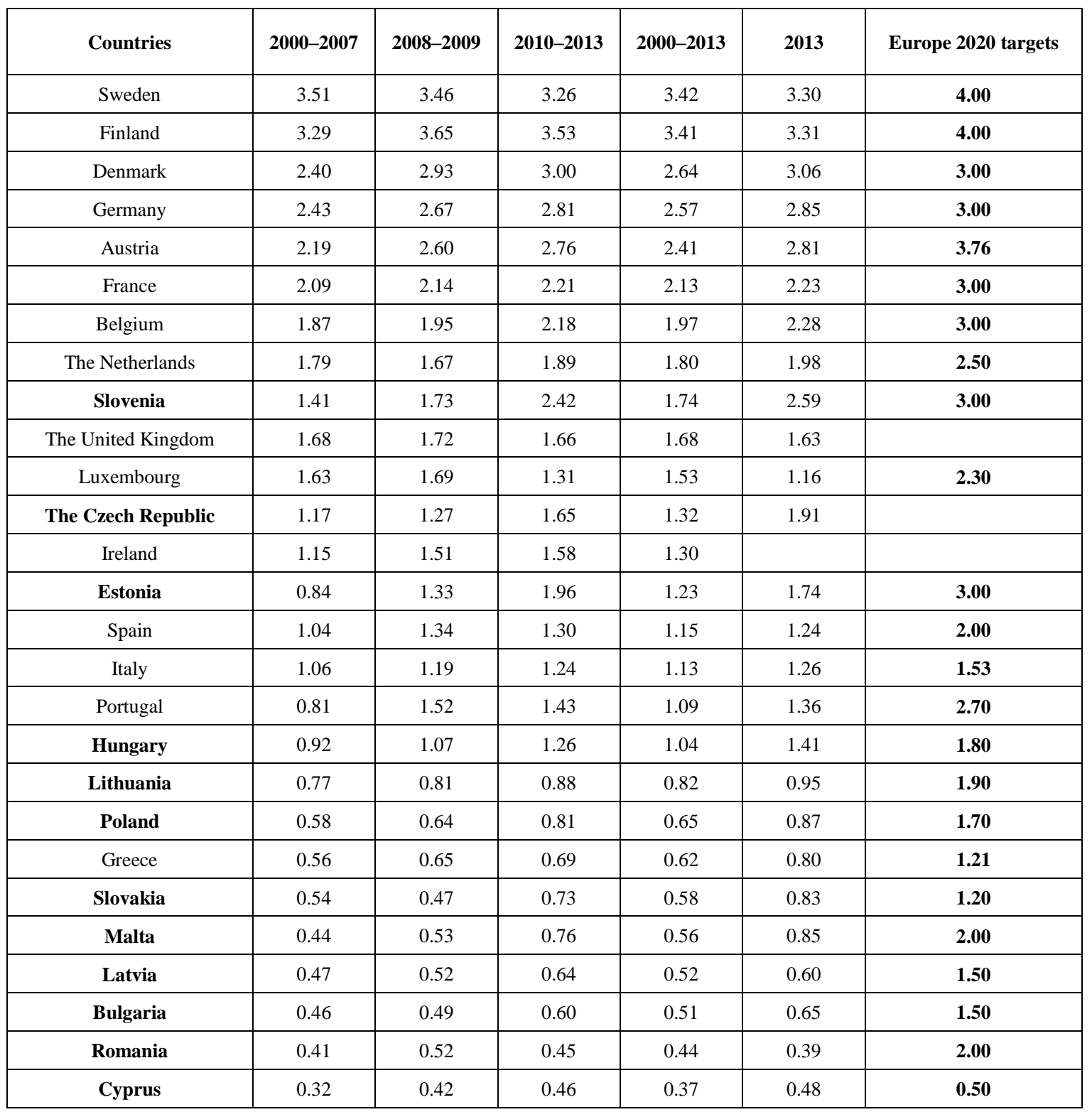

*Averages from 2000-2007, 2008-2009, 2010-2013, and value in 2013.

Source: Eurostat database 
The 5 countries with the highest level of $R \& D$ expenditures as a share of GDP in the period of analysis are: Sweden, Finland, Denmark, Germany, and Austria. Countries shown in bold are new EU members (joined after 2004) and mostly situated at the bottom of the table, indicating that they spend less than half as much as leading countries, even more - most of these countries have R\&D intensity below $1 \%$ of GDP. Countries with relatively low R\&D intensity in the table are generally less developed than those that spend a lot, although some of lower R\&D spenders had high GDP growth rates during the recovery period after the recent crisis. Generally, between 2000 and 2007, the EU27 followed a relatively stable trend of $1.8 \%$ in gross domestic expenditure on R\&D as a percentage of GDP (Europe 2020, 2015). Since then it has grown marginally. This was due to the combined effects of the crisis on GDP growth and an increase in nominal government R\&D spending to combat the long-term impacts of the crisis. The reasons for the increase between 2007 and 2009 include GDP falling more rapidly than overall R\&D expenditure and the actions taken by individual EU member states to step up public R\&D investment (Europe 2020, 2015). Between 2010 and 2013 , R\&D rates had grown, but for almost all countries remained far from their national R\&D targets under Europe 2020 (the last column in Table II).

\section{RESULTS}

The main results of our analysis are presented in Table III. As panel data modelling results are very sensitive to the specification of the model, four models with different sets of explanatory variables are presented.

All reported models in Table III were estimated using first difference GMM procedure of Arellano, Bond (1991) with robust standard error, consistent with panel-specific autocorrelation and heteroscedasticity. That allowed removing the individual effects. Some variables like $R D$ and FDI might suffer endogeneity problems with respect to the GDP growth; therefore, we used the following instruments: lagged values of $\ln G D P, \ln R D$ and $\ln F D I$. Instrumental variables were tested with the Hansen $\mathbf{J}$ test. Respective null hypothesis is that there are no correlations between instruments and residuals. Results ( $p$-values) are shown in Table III. Autocorrelation problem was tested with the Arellano-Bond test for 1 and 2 lags. For all reported models Arellano-Bond test could not reject the null hypothesis of absence of autocorrelation in the residuals.

TABLE III

DYNAMIC PANEL REGRESSION RESULTS

\begin{tabular}{|c|c|c|c|c|c|c|}
\hline Variable & Model 1 & Model 2 & Model 3 & Model 4 & Model_2.1 & Model_3.1 \\
\hline Short-run estimates & \multicolumn{4}{|c|}{ All EU countries } & \multicolumn{2}{|c|}{ New EU member states } \\
\hline $\ln G D P_{i, t-1}$ & $\begin{array}{c}0.797 * * * \\
(0.016)\end{array}$ & $\begin{array}{c}0.787 * * * \\
(0.018)\end{array}$ & $\begin{array}{c}0.759 * * * \\
(0.005)\end{array}$ & $\begin{array}{c}0.749 * * * \\
(0.009)\end{array}$ & $\begin{array}{c}0.510^{* * *} \\
(0.112)\end{array}$ & $\begin{array}{c}0.695 * * * \\
(0.057)\end{array}$ \\
\hline $\ln K_{i, t}$ & $\begin{array}{c}0.145 * * * \\
(0.044)\end{array}$ & $\begin{array}{c}0.161 * * * \\
(0.049)\end{array}$ & $\begin{array}{c}0.111 * * * \\
(0.016)\end{array}$ & $\begin{array}{l}0.109 * \\
(0.056)\end{array}$ & $\begin{array}{c}0.413 * * * \\
(0.049)\end{array}$ & $\begin{array}{c}0.138 * * * \\
(0.028)\end{array}$ \\
\hline $\ln F D I_{i, t}$ & $\begin{array}{c}0.134 * * * \\
(0.043)\end{array}$ & $\begin{array}{c}0.149 * * * \\
(0.048)\end{array}$ & $\begin{array}{c}0.103 * * * \\
(0.016)\end{array}$ & $\begin{array}{l}0.096^{*} \\
(0.057)\end{array}$ & $\begin{array}{l}0.421 * * * \\
(0.076)\end{array}$ & $\begin{array}{c}0.113 * * * \\
(0.038)\end{array}$ \\
\hline $\ln R D_{i, t}$ & $\begin{array}{c}0.020 * * * \\
(0.002)\end{array}$ & $\begin{array}{l}0.018^{* * *} \\
(0.003)\end{array}$ & $\begin{array}{c}0.028 * * * \\
(0.002)\end{array}$ & $\begin{array}{l}0.021 * * * \\
(0.001)\end{array}$ & $\begin{array}{l}0.036^{*} \\
(0.019)\end{array}$ & $\begin{array}{c}0.043^{* *} \\
(0.023)\end{array}$ \\
\hline $\ln H C_{i, t}$ & & $\begin{array}{c}0.011 * * * \\
(0.003)\end{array}$ & & $\begin{array}{c}0.022 * * \\
(0.009)\end{array}$ & $\begin{array}{c}0.204 * * \\
(0.084)\end{array}$ & \\
\hline G_balance & & & $\begin{array}{l}0.002 * * * \\
(0.0004)\end{array}$ & $\begin{array}{l}0.002 * * * \\
(0.0005)\end{array}$ & & $\begin{array}{l}0.004 * * \\
(0.001)\end{array}$ \\
\hline Long-run (deduced values) & \multicolumn{4}{|c|}{ All EU countries } & \multicolumn{2}{|c|}{ New EU member states } \\
\hline ECM coefficient $\phi$ & $-0.203^{* * *}$ & $-0.213 * * *$ & $-0.241^{* * *}$ & $-0.251 * * *$ & $-0.490 * * *$ & $-0.305 * * *$ \\
\hline $\ln K_{i, t}$ & $0.711 * *$ & $0.756^{* *}$ & $0.461 * * *$ & $0.433^{*}$ & $0.843^{* *}$ & $0.451 *$ \\
\hline $\ln F D I_{i, t}$ & $0.658 * * *$ & $0.699 * * *$ & $0.426^{* * *}$ & $0.385^{*}$ & $0.858 * * *$ & $0.369^{*}$ \\
\hline $\ln R D_{i, t}$ & $0.099 * *$ & $0.084 * * *$ & $0.117^{* * *}$ & $0.084 * * *$ & $0.082^{* *}$ & $0.228 *$ \\
\hline $\ln H C_{i, t}$ & & $0.052 * * *$ & & $0.086^{* *}$ & $0.416^{*}$ & \\
\hline G_balance & & & $0.008^{* * *}$ & $0.008^{* * *}$ & & $0.015^{*}$ \\
\hline Hansen test ( $p$-value) & 0.250 & 0.158 & 0.398 & 0.458 & 0.102 & 0.098 \\
\hline $\begin{array}{l}p \text {-value from the Arellano-Bond test } \\
\text { with } 2 \text { lags }\end{array}$ & 0.312 & 0.331 & 0.354 & 0.124 & 0.099 & 0.412 \\
\hline Number of observations (adjusted) & 324 & 324 & 309 & 311 & 143 & 129 \\
\hline
\end{tabular}
Notes:

1) Dependent variable: growth rate of real GDP per employee $\left(\ln G D P_{i, t}\right)$;

2) Values in brackets are standard errors;

3) $*, * *, * * *$ denote significance levels of $10 \%, 5 \%$ and $1 \%$, respectively. 
In all specifications, our results show a positive, statistically significant relationship between R\&D and GDP per person employed. The elasticities imply that a $10 \%$ increase in R\&D intensity should generate an increase of about $0.2 \%$ in the shortrun growth (with ceteris paribus assumption). Long-run coefficients presented in Table III were calculated from the error correction model form (Formulas 3 and 4) and suggested that a $10 \%$ permanent increase in R\&D should generate about $0.9 \%$ increase in the growth of GDP per person employed in the long run (with ceteris paribus assumption). Standard errors for the long-run effect were obtained by the delta-method (Papke \& Wooldridge, 2005). Estimated parameters were stable; they did not change when we introduced additional variables like proxy of human capital or government balance. Human capital appeared to be significant in short- and long-run estimations, and suggested that as proportion of labour force with tertiary education increased by $10 \%$, GDP per person employed should increase approximately by $0.1 \%$ to $0.2 \%$ in the short run. Respective change in the long run was about $0.5 \%$. Regression results for new EU member states slightly differ from the whole panel of EU 27. Estimated coefficient of R\&D in a panel of EU12 is statistically significant just with $\alpha=10 \%$.

The Error Correction term $\phi$ was also statistically significant in all specifications; it was negative, representing convergence towards the steady state. Value of about -0.2 is a typical result in the empirical literature, where it usually varies from -0.6 to -0.2 .

New EU member states were of our special interest, because in the early 2000s they started with quite similar very low $R \& D$ intensities. Later, the dynamics of R\&D expenditures became more heterogeneous. However, the average R\&D intensity for the period of analysis (2000-2013) was still lower than it should be, and only four countries - Slovenia, the Czech Republic, Estonia and Hungary - had R\&D intensity above $1 \%$ on average (see Table II).

Heterogeneity in the sample raises an idea that there can be differences in the size of the spillover effect of $R \& D$ expenditures to GDP growth. Table II shows that some of new EU member states managed to increase their expenditures on research and development more than others. As it was mentioned above, during the period of 2000-2013 only 4 new EU member states had the R\&D expenditures as percentage of GDP that was more than $1 \%$ (on average), while for the rest of new member states this percentage was less than $1 \%$. Greece - one of the old EU member state - also had low R\&D expenditure level.

In the data analysis we introduced two additional dummy variables in order to compare $\mathrm{R} \& \mathrm{D}$ elasticities with respect to their size as percentage of GDP: $d \_l o w$ and $h \_h i g h$. The variable $d \_l o w$ has value 1 for all countries with $R \& D$ ratio to GDP less than $1 \%$ (on average during the period 2000-2013, 9 lower countries in Table II), and value 0 for all other countries. Meanwhile, the variable $d \_h i g h$ has value 1 for upper 6 countries in Table II, and $0-$ for the rest. The rest of the countries are the base or benchmark group.

The estimation procedure was repeated keeping the same model specification, instruments and the method, but the previously mentioned new series were included in the regression equation as slope dummies. Estimation results are presented in the table below (Table IV).

TABLE IV

Dynamic PANel Regression Results: Estimation with R\&D Ratio Dummies

\begin{tabular}{|c|c|c|c|}
\hline Variable & Model 5 & Model 6 & Model 7 \\
\hline \multicolumn{4}{|c|}{ Short-run estimates } \\
\hline $\ln G D P_{i, t-1}$ & $\begin{array}{l}0.293 * * * \\
(0.028)\end{array}$ & $\begin{array}{c}0.269 * * * \\
(0.041)\end{array}$ & $\begin{array}{c}0.295^{* * * *} \\
(0.051)\end{array}$ \\
\hline $\ln K_{i, t}$ & $\begin{array}{c}0.473 * * * \\
(0.083)\end{array}$ & $\begin{array}{c}0.483 * * * \\
(0.08)\end{array}$ & $\begin{array}{c}0.600 * * * \\
(0.070)\end{array}$ \\
\hline $\ln F D I_{i, t}$ & $\begin{array}{c}0.467 * * * \\
(0.082)\end{array}$ & $\begin{array}{c}0.495 * * * \\
(0.019)\end{array}$ & $\begin{array}{c}0.500^{* * * *} \\
(0.071)\end{array}$ \\
\hline $\ln F D I_{i, t} \cdot D \_L O W$ & & & $\begin{array}{c}0.250^{* * * *} \\
(0.041)\end{array}$ \\
\hline $\ln R D_{i, t}$ & $\begin{array}{c}0.038 * * * \\
(0.006)\end{array}$ & $\begin{array}{c}0.029 * * * \\
(0.001)\end{array}$ & $\begin{array}{c}0.040 * * * \\
(0.005)\end{array}$ \\
\hline $\ln R D_{i, t} \cdot D_{-} L O W$ & $\begin{array}{c}0.065 * * * \\
(0.011)\end{array}$ & $\begin{array}{c}0.064 * * * \\
(0.021)\end{array}$ & $\begin{array}{c}0.060^{* * * *} \\
(0.010)\end{array}$ \\
\hline $\ln R D_{i, t} \cdot D_{-} H I G H$ & & $\begin{array}{c}0.281 \\
(0.198)\end{array}$ & \\
\hline $\ln H C_{i, t}$ & $\begin{array}{c}0.128 * * * \\
(0.018)\end{array}$ & $\begin{array}{c}0.114 * * * \\
(0.003)\end{array}$ & $\begin{array}{c}0.100 * * * \\
(0.025)\end{array}$ \\
\hline G_balance & $\begin{array}{c}0.0029 * * * \\
(0.0003)\end{array}$ & & \\
\hline Hansen test ( $p$-value) & 0.197 & 0.196 & 0.190 \\
\hline $\begin{array}{l}p \text {-value from the Arellano-Bond test } \\
\text { with } 2 \text { lags }\end{array}$ & 0.139 & 0.962 & 0.276 \\
\hline Number of observations (adjusted) & 309 & 324 & 324 \\
\hline
\end{tabular}

Notes:

1) Dependent variable: growth rate of real GDP per employee $\left(\operatorname{lnGDP}_{i, t}\right)$;

2) Values in brackets are standard errors;

3) $*, * *, * * *$ denote significance levels of $10 \%, 5 \%$ and $1 \%$, respectively. 
The results of regression analysis, using $R \& D$ level dummies, are presented in Table IV. We can see that there are no statistically significant differences in the short-run R\&D elasticities for medium and high R\&D to GDP ratio groups. For low R\&D countries, the estimated partial elasticity is approximately by 0.06 percent points higher than for other countries.

Robustness of the results was tested in different ways. Firstly, we paid attention to calculation of capital $(R \& D$ and physical capital) stocks: there was uncertainty about the appropriate depreciation rate used in the PIM. Obviously, alternative assumptions might produce different results. We tried alternative depreciation rates (between $5 \%$ and $30 \%$ a year), and received that selection of a depreciation rate in the range between $5 \%$ and $15 \%$ did not affect the general trends (results are available upon request). Secondly, we tried several subperiods assuming that the results could possibly be affected by outliers during the recent crisis. We found that introduction of these time dummies did not qualitatively change the results. We also tried 3 and 4 years moving averages for the variables. R\&D coefficients remained to be statistically significant. Thirdly, we tried different sub-panels of countries to make sure that we eliminated all individual effects. Our main interest lied in the comparison of R\&D effects in new EU member states (joined in 2004 and later) with the results obtained for old EU member states. Probably due to higher heterogeneity in the data, results for new EU countries were not so stable, and estimation results showed that R\&D coefficients were statistically significant just for $90 \%$ level. Actually, a similar result was reported by Silaghi et al. (2014) for the period of 1998-2007. They emphasised importance to distinct types of $R \& D$, and found for $C E E$ countries statistically significant impact of R\&D business on economic growth, while total R\&D was not important.

\section{CONCLUSION}

The results obtained in the research were consistent with theoretical and empirical findings of previous studies. Empirical analysis confirmed statistically significant impact of R\&D expenditure stocks on growth in real GDP per person employed in the EU countries. The same conclusion was also obtained for the set of new EU member states. However, due to the high heterogeneity in this sub-sample, significance of estimated coefficients decreased. Therefore, more homogenous groups of countries were created taking into account R\&D and GDP ratio. For low R\&D expenditures (less than $1 \%$ per GDP) research and development activities are even more important and necessary for GDP growth.

These findings maintain that in order to ensure sustainable economic growth performance, it is necessary to allocate more resources to $R \& D$ activities.
Long-run effects are higher than short-run ones. Estimates varied for different subsamples. Estimation results for EU12 sub-sample were not conclusive. The analysis could be continued by distinguishing between effects of private and public R\&D investments. As descriptive statistics showed high heterogeneity within the EU countries, in further analysis it should be important to consider more factors that influence R\&D effectiveness - such as institutional framework, number of patents, type of R\&Ds, sectors of performance, quality of human capital etc.

\section{REFERENCES}

Europe 2020. (2015). European strategy for smart, sustainable and inclusive growth. Retrieved August 28, 2015, from http://ec.europa.eu/eurostat/statistics-

explained/index.php/Europe_2020_indicators__research_and_development

Arellano, M., Bond, S. (1991). Some Tests of Specification for Panel Data: Monte Carlo Evidence and an Application to Employment Equations. The Review of Economic Studies, 58(2), 277-297. http://dx.doi.org/10.2307/2297968

Caselli, F., Esquivel, G. \& Lefort, F. (1996). Reopening the convergence debate: a new look at cross country growth empirics. Journal of Economic Growth, 1, 363-389. http://dx.doi.org/10.1007/BF00141044

Erins, I. \& Vitola, L. (2014). R\&D Expenditures by Sectors of Performance and Analysis of Performance Indicators in the Baltic States. Procedia-Social and behavioural Sciences, 156, 334-339.

http://dx.doi.org/10.1016/j.sbspro.2014.11.198

Goel, R. K. \& Ram. R. (1994). Research and development expenditures and economic growth: a cross - country study. Economic Development and Cultural Change, 42(2), 403-411. http://dx.doi.org/10.1086/452087

Gumus, E. \& Celikay, F. (2015). R\&D Expenditure and Economic Growth: New Empirical Evidence. The Journal of Applied Economic Research, 9(3), 205-217. http://dx.doi.org/10.1177/0973801015579753

Huňady, J. \& Orviská, M. (2014). The Impact of Research and Development Expenditures on Innovation Performance and Economic Growth of the Country - the Empirical Evidence. CBU International Conference Proceedings 2014, 2, 119-125. http://dx.doi.org/10.12955/cbup.v2.454

Krammer, S. (2010). International R\&D spillovers in emerging markets: The impact of trade and foreign direct investment. Journal of International Trade \& Economic Development, 19(4), 591-623. http://dx.doi.org/10.1080/09638190902792464

Papke, L. E. \& Wooldridge, J. M. (2005). A computational trick for deltamethod standard errors. Economics Letters, 86, 413-417. http://dx.doi.org/10.1016/i.econlet.2004.07.022

Parham, D. (2009). Empirical analysis of the effects of R\&D on productivity: Implications for productivity measurement? Chapter in OECD/FSO: Productivity measurement and analysis, 337-355. http://dx.doi.org/10.1787/9789264044616-en

Romer, P. (1994). The Origins of Endogenous Growth. Journal of Economic Perspectives, 1, 3-22. http://dx.doi.org/10.1257/jep.8.1.3

Sequeira, T. N. (2008). On the effects of human capital and R\&D policies in an endogenous growth model. Economic Modelling, 25(5), 968-982. http://dx.doi.org/10.1016/j.econmod.2008.01.002

Silaghi, M., Alexa, D., Jude, C., \& Litan, C. (2014). Do business and public sector research and development expenditures contribute to economic growth in Central and Eastern Europe Countries? A dynamic panel estimation. Economic Modelling, 36, 108-119. http://dx.doi.org/10.1016/j.econmod.2013.08.035

Svensson, R. (2008). Growth through Research and development - what does the research literature say? VINNOVA REPORT VR 2008:19, 72. 


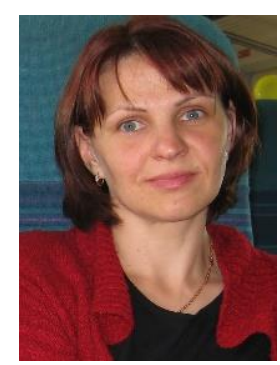

Rita Freimane holds the Master's degree in Mathematics from the University of Latvia, now after Doctoral studies in Economics (Econometrics) develops her $\mathrm{PhD}$ Thesis. At present, she is a Lecturer at the Faculty of Economics and Management, University of Latvia. She is a member of the Latvian Econometrician Association.

E-mail: rita.freimane@lu.lv

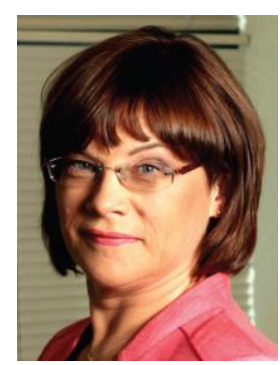

Signe Bāliṇa obtained the Doctoral degree in Economics (Econometrics) in 2002 and at present is a Professor at the University of Latvia, Faculty of Economics and Management.

Since 2009, Signe Bālina has been a President of the Latvian Information and Communications Technology Association (LIKTA) that is a professional association uniting organisations of ICT industry, research and educational institutions, as well as ICT professionals. Main objectives of LIKTA are development of information society and growth of ICT industry.

Since 2010 Signe Bālina has been a Chairperson of the Board of "IT Competence Centre", which promotes a long-term cooperation between ICT enterprises and science institutions in the fields of natural language technologies and business process analysis technologies.

E-mail: signe.balina@lu.lv 